University of Nebraska - Lincoln

DigitalCommons@University of Nebraska - Lincoln

Political Science Department -- Theses,

Dissertations, and Student Scholarship

Political Science, Department of

9-2-2007

\title{
Ganging Up Against the Courts: Congressional Curtailment of Judicial Review, 1988-2004
}

\author{
Benjamin J. Keele \\ University of Nebraska-Lincoln
}

Follow this and additional works at: https://digitalcommons.unl.edu/poliscitheses

Part of the Political Science Commons

Keele, Benjamin J., "Ganging Up Against the Courts: Congressional Curtailment of Judicial Review, 1988-2004" (2007). Political Science Department -- Theses, Dissertations, and Student Scholarship. 2. https://digitalcommons.unl.edu/poliscitheses/2

This Article is brought to you for free and open access by the Political Science, Department of at DigitalCommons@University of Nebraska - Lincoln. It has been accepted for inclusion in Political Science Department -- Theses, Dissertations, and Student Scholarship by an authorized administrator of DigitalCommons@University of Nebraska - Lincoln. 
This work is licensed under the Creative Commons Attribution 3.0 Unported License. To view a copy of this license, visit http://creativecommons.org/licenses/by/3.0/ or send a letter to

Creative Commons

171 Second Street, Suite 300

San Francisco, California, 94105, USA 


\title{
Ganging Up Against the Courts: Congressional Curtailment of Judicial Review, 1988-2004
}

\author{
Benjamin Keele, University of Nebraska-Lincoln
}

The Constitution grants Congress the power to regulate the jurisdiction of the federal courts. Congress has sought to exercise this power throughout its history, especially when the courts have issued a decision or series of decisions that are very unpopular. The precise nature of Congress' authority in this area is controversial and scholars have proposed many criteria and theories to delineate the legislative and judicial branches' respective powers. This study, examining the number of times Congress has categorically denied the courts' jurisdiction over a defined set of cases between 1988 and 2004, finds that Congress has denied jurisdiction 166 times. This practice, while currently relatively narrow, could have major implications for the balance of powers between the three branches of the federal government and the vindication of individual rights if allowed to become more prevalent.

The United States Constitution (art. 3, sec. 2, cl. 2) provides that: In all Cases affecting Ambassadors, other public Ministers and Consuls, and those in which a State shall be Party, the supreme Court shall have original Jurisdiction. In all the other Cases before mentioned, the supreme Court shall have appellate Jurisdiction, both as to Law and Fact, with such Exceptions, and under such Regulations as the Congress shall make.

Under this authority, Congress has denied the courts the power to hear certain kinds of cases. When the courts have issued controversial decisions, legislators often propose preventing the courts from continuing to make unpopular decisions by denying them jurisdiction over those cases. The scope of Congress' authority to curtail judicial review is subject to scholarly and political disagreement.

I will examine the history of the executive and legislative branches' efforts to curtail the jurisdiction of the federal judicial branch. I will also review the scholarly debate over the power of Congress to curtail review over cases involving constitutional rights. However, little has been written on Congress' restricting review of cases concerning statutory law. Then, I will study how often and in 
what ways Congress has denied judicial review from 1988 to 2005 . Finally, I will discuss how Congress' empirical practices toward judicial review have implications for separation of powers, open governance and individual rights.

\section{Historical Attempts to Deny Jurisdiction}

In the past, lawmakers have attempted to limit the jurisdiction of the courts as a response to unpopular decisions. After decrying the unpopular decisions, legislators have tended to declare the judiciary an undemocratic institution that must be brought to heel by the majoritarian legislative branch.

The concept of judicial review was first introduced to federal constitutional jurisprudence in Marbury v. Madison (1803). Marbury established that the courts, as interpreters of the laws and the Constitution, had the power to invalidate laws and actions that were inconsistent with the Constitution. This power has made the courts a major influence in the political process of enacting legislation. Many laws that passed muster in the more political, majoritarian institutions have been struck down by the courts. There is considerable debate concerning the proper role of the courts in America's political system and how much deference legislatively approved measures deserve from the courts. I will not attempt to address that issue directly, but I will briefly review how Congress has tried to reduce judicial review in order to increase its relative power and implement its policy preferences.

Using the authority articulated in Marbury, the Court began invalidating state laws in the first decades of the $1800 \mathrm{~s}$. Unsurprisingly, these decisions were not popular with state officials and their representatives in Congress.

The first congressional attempts to repeal Supreme Court jurisdiction were occasioned by the Court's early decisions overturning state laws. Section 25 of the Judiciary Act of 1789 authorized the Supreme Court to review, and therefore declare invalid, decisions of the states' highest courts that upheld state laws challenged as conflicting with the federal Constitution, federal statutes, or treaties. With each successive ruling striking down a state law, opposition to Section 25 grew among proponents of states' rights (Biskupic and Witt 1997, 337). 
Proposals were introduced to repeal Section 25 and thus deprive the Court of hearing any state court decisions upholding a state law challenged on federal grounds. While the proposals were never even passed by a single house of Congress, the justices and supporters of the Court were deeply concerned by the move (Biskupic and Witt 1997, 337-38). The Court later declined an opportunity to expand its jurisdiction over state court decisions, portending the future influence that attempted jurisdictional restrictions, even failed ones, could have on courts' decision-making.

While the first attempt to restrict the judiciary's jurisdiction was unsuccessful, the second major attempt utterly succeeded, stopping the Supreme Court from deciding a case over which it was deliberating. After defeating the Confederacy in the Civil War, Congress enacted the Reconstruction Acts of 1867, placing the southern states under military rule until they met certain conditions, one of which was ratifying the Fourteenth Amendment to ensure equal protection of the laws for the recently emancipated slaves. Congress had also recently granted the Court jurisdiction over habeas corpus appeals. "Seeking to protect blacks and federal officials in the South from harassment by white southerners, Congress in February 1867 enacted a statute expanding the Supreme Court's jurisdiction to review denials of writs of habeas corpus" (Biskupic and Witt 1997, 338). A case would soon arise that would make Congress reconsider the wisdom of its decision.

William $\mathrm{H}$. McCardle was the editor of a Mississippi newspaper. Displeased with the military government, he frequently attacked the generals and called for whites to resist reforms to grant blacks political influence. Major General Edward O.C. Ord, the commander of the military district in which McCardle published, finally tired of McCardle's complaints and charged him with several offenses, including inciting insurrection and libel. Ord charged McCardle in a military court. McCardle argued that trying him before a military court was unconstitutional and filed a petition for habeas corpus. The trial court denied habeas corpus and McCardle used the 1867 statute to appeal to the Supreme Court.

The Court heard arguments in the case and, given the Court's disapproval of trying civilians in military courts while civilian courts were available (Ex Parte Miligan 1866), Republicans rightly feared that McCardle's incarceration (and the Reconstruction Acts that authorized it) would be invalidated. They managed to insert an 
amendment to withdraw the Court's jurisdiction over writs of habeas corpus and any such cases before it. The bill was enacted over the veto of President Andrew Johnson. The Court then duly dismissed McCardle's case before it was able to rule on the merits. "Chief Justice Salmon P. Chase wrote that the Constitution gave Congress the authority to make exceptions to the Court's appellate jurisdiction and that Congress had expressly exercised that authority" (Biskupic and Witt 1997, 339). Thus, Congress was able to preserve the Reconstruction Acts.

The circumstances of this successful denial of jurisdiction show some of the ingredients of such restrictions: cases preceding the denial were sufficiently unpopular to garner great support for denying jurisdiction, the denial would permit the execution of policy that Congress preferred, and supporters of the courts did not persuasively advocate for maintaining a relatively strong judiciary. These ingredients will help show why some congressional denials of jurisdiction pass, while the vast majority of those proposed do not.

Lawmakers have habitually introduced bills to curb the courts' jurisdiction.

The congressional weapon that is probably most often raised against the federal judiciary is that of curtailing its jurisdiction. Countless efforts of this kind have been recorded; casual perusal of Charles Warren's Supreme Court history for the nineteenth century alone discloses their occurrence in $1808,1821,1822,1824,1825,1826$, $1830,1831,1832,1833,1846,1858,1867,1868,1871$, 1872 , and 1882 . Almost every occasion is clearly traceable to momentous constitutional rulings, most of them declarations of unconstitutionality (Choper 1980, 145).

The judiciary's jurisdiction has not been free from attack in the twentieth century either. The Portal-to-Portal Act eliminated the jurisdiction of the state and federal courts over rights to portal-toportal pay under the Fair Labor Standards Act of 1938. Bills to limit judicial review were proposed in 1957 and 1958. It had only been a few years since Brown v. Board of Education of Topeka (1954), and the Court had also issued several decisions relating to national security that frustrated legislators' quest to root out Communists from positions of influence. The Court, then, was not very popular with some lawmakers. On July 26, 1957, Senator William E. Jenner 
of Indiana introduced a bill to deny jurisdiction over the following areas: admissions to practice law in state courts, proceedings before and functions of congressional committees, employee loyaltysecurity programs, and state regulations against subversive activities and school board rules relating to subversive activities among teachers (Pritchett 1961, 31). Each of these denials related to a decision by the Court of which Jenner disapproved.

Unlike the circumstances in the McCardle denial, opponents to Jenner's bill were able to take action to interrupt its progress. "Because of the widespread opposition which had been expressed against the device of limiting the Court's appellate jurisdiction, four of the subjects which the original Jenner bill had forbidden the Court to touch were dropped" (Pritchett 1961, 32). Instead of denying jurisdiction to the Court, the bill was amended to reverse the controversial decisions by amending the statutes the Court had been interpreting. The jurisdictional denial relating to state bar admissions rules was left intact. However, what remained in the bill was ultimately moot because it was defeated in the Senate.

Several factors contributed to the failure of the Jenner bill. First, Pritchett suggests that respect for the Supreme Court as an institution was a primary factor. "Basically, the Court was protected by the respect which is so widely felt for the judicial institution in the United States... a great part of opinion in the United States holds that the Supreme Court should be let alone, or rather that it should be subject to influence only in the accepted manner, namely, by use of the appointing power when vacancies occur" (Pritchett 1961, 119). Pritchett wrote this in 1961, but respect for the Supreme Court has remained relatively high, even though recent controversies have somewhat tarnished its public image. "Currently, 57\% of Americans have a favorable impression of the Supreme Court, with $30 \%$ expressing an unfavorable view. In the past, favorable views of the court surpassed 70\%" (Pew Research Center 2005). Even though the Pew study indicated that the Court's reputation had fallen due to partisan fighting over nominations to the Court, over half of Americans polled still thought highly of the Court. This respect has been integral to warding off most proposals to strip the courts of jurisdiction over entire swaths of legal territory. However, as I will later show, it has hardly immunized the courts from smaller, less visible, piecemeal curtailment.

Pritchett also mentions as reasons the bill failed the motives of the proponents of jurisdiction-stripping and the timbre of their 
rhetoric. While northern Democrats voted to preserve the Court's jurisdiction, southern Democrats voted for Jenner's bill to limit the Court that had mandated desegregation. "It is paradoxical but probably true that the segregation issue increased the bitterness of the legislative drive against the Court and at the same time guaranteed the defeat of the attack" (Pritchett 1961, 120). Some lawmakers also exaggerated the negative effect the Court's rulings would have on national security. This hyperbole decreased the credibility of advocates for denial of jurisdiction.

Another possible variable in the conflict between the Court and Congress was the Court's own behavior following the introduction of the jurisdiction-limiting bills. Terri Jennings Peretti argues that the threat posed by the Jenner bill influenced the Court's jurisprudence.

Although the Jenner Bill restricting the Court's jurisdiction was defeated in the Senate (by only a 41 to 49 vote), the fierce congressional reaction appears to have had its desired effect. In 1959, the Court upheld HUAC authority in Barenblatt v. U.S. and state authority to investigate subversive activities in Uphaus v. Wyman. What Walter Murphy terms a "tactical withdrawal" is further substantiated by a 20 percent increase in the rate at which the Court rejected civil liberties claims from the 1956 to 1958 term (Peretti 1999, 140).

However, Pritchett argues that the Jenner bill had no effect on the Court's later decisions. "The danger of retaliatory legislation had largely passed by the time the Court handed down Barenblatt, Uphaus, and the other conciliatory decisions. The Court did not 'save' itself by these decisions. It had already been saved because a majority in the two houses of Congress was not disposed...to use legislative power to override judicial determinations" (Pritchett $1961,121)$. Even if the rulings that were issued immediately after the threat had passed were not influenced in any way, it is entirely possible that the justices wished to avoid such threats in the future by writing less controversial decisions and letting Congress' anger subside.

Near the end of his book, Pritchett declares that "[i]t seems quite possible that the Supreme Court's victory in this controversy has had the effect of permanently neutralizing what is perhaps the most drastic congressional authority over the Court, the control of its 
appellate jurisdiction" (Pritchett 1961, 121-22). Later events would render his conclusion premature, if not incorrect. Controversial, high-profile decisions have stimulated calls for jurisdictional restrictions for the past thirty years.

Burger Court rulings on abortion and school busing prompted a wave of jurisdiction-stripping bills in the 1970s. An amendment proposed by Senator Jesse Helms of North Carolina in 1979 would have deprived courts of jurisdiction over voluntary school prayer. In the 1980 s bills were introduced to remove jurisdiction over abortion, school prayer and male-only military draft cases. Like their predecessors in the late 1950 s, none of these bills was enacted into law. Nonetheless, jurisdiction-stripping remains a viable congressional tool to this day, albeit often in a less conspicuous form.

Within the past few years, several court decisions have again prompted calls to restrict the judiciary's jurisdiction. In 2002, the United States Court of Appeals for the Ninth Circuit ruled that requiring the recitation of the Pledge of Allegiance in public school classrooms violated the First Amendment because the words "under God" constituted an establishment of religion (Newdow v. U.S. Congress 2002). The highest courts of Vermont and Massachusetts have mandated same-sex civil unions or marriage, respectively. This led some legislators to fear that a federal court would eventually invalidate the Defense of Marriage Act, a law that allows states to refuse to recognize marriage licenses issued to same-sex couples in other states. Legislators have responded by introducing provisions to remove the courts' jurisdiction over the Defense of Marriage Act and the Pledge of Allegiance.

The House Judiciary Committee's report on the Marriage Protection Act argued that "Congress must exercise its constitutional authority to limit the jurisdiction of the Federal courts to ensure that the states, and not unelected Federal judges, have the final say on whether they must accept same-sex marriage licenses issued in other states" (U.S. House Committee on the Judiciary 2004, 4). This invocation of congressional power to limit jurisdiction demonstrates that this tool is far from neutralized. In 2004, the House passed the Marriage Protection Act and the Pledge Protection Act (Bazon, Killian and Thomas 2005, 10). At present, none of these high-profile proposals have been passed by the Senate. However, since at least 1988 (and probably much before then), Congress has been exercising its power over the courts' jurisdiction to insulate less well-publicized 
decisions and rules from judicial review.

\section{The Scope of Congress' Power to Regulate Jurisdiction}

Along with efforts in Congress to limit jurisdiction have come reams of scholarly writings arguing over the exact scope of Congress's authority. The literature is voluminous to the point of unwieldiness. "[O]ne might expect that the ultimate tribunal -- that of academics (who, unlike the Justices, often claim infallibility even though they lack finality) -- would have reached a consensus after more than a century and a half of scrutiny. But I can assure you that there is no such consensus" (Gunther 1984, 897). Commenting on why limiting the jurisdiction of the courts is so controversial, Mark Tushnet and Jennifer Jaff $(1984,1328)$ write, "we suggest that those concerns [over judicial jurisdiction] arise from disquiet over the fundamental structure of the Constitution...the practices of politics and judging no longer meet the demands of a sound constitutional order." They hypothesize that most citizens no longer have confidence that the Constitution itself will limit the courts' discretion to decree policy by judicial fiat. Thus, the power of the judiciary is increased (at least perceptually) and the boundaries of the courts' power become more politically important.

Whatever the cause of the topic's popularity, a proper treatment of all the disparate theories regarding Congress' power to curtail the courts' jurisdiction would overwhelm the other parts of this study. In addition, most of the debate concerns Congress' power to deny a judicial forum for constitutional rights. Most commentators seem to take for granted that Congress may alter the courts' jurisdiction over statutory issues at will. Perhaps that alone helps explain why Congress frequently deprives the courts of jurisdiction over statutory issues and, despite an impressive amount of discussion, fails to enact legislation that pertains to higher-profile constitutional issues. Therefore, I will attempt to provide only a brief review of some of the most salient theories on restricting judicial review. This should supply adequate theoretical context to the historical and empirical evidence of Congress' practices in this area.

Broadly speaking, the plethora of views on Congress' power over the courts' jurisdiction can be arrayed on a spectrum. One end represents the view that Congress is plenipotentiary with respect to the courts and can grant or withhold jurisdiction at its discretion. On the other end is the opinion that the Constitution requires Congress to 
grant jurisdiction to the courts and that jurisdiction itself is constitutionally protected from diminution. In the middle, then, is a large variety of permutations of these two extremes. Some types of jurisdiction can be limited by Congress while others cannot; under certain conditions Congress can limit the courts' jurisdiction, as long as some tribunal (state, specially established, or otherwise) is available, jurisdiction can be denied to all others. A few representative examples will suffice to illustrate this spectrum.

The first theory is what Edward Keynes and Randall K. Miller (1989) term the plenary view. Under this view, the language in Article III mentioning exceptions and regulations to the courts' jurisdiction authorizes Congress to confer as much or as little jurisdiction as it sees fit. "Unless Congress enacts jurisdictional legislation, the Supreme Court cannot exercise its appellate jurisdiction. Once Congress has acted, as John Marshall observed, the Court cannot exercise jurisdiction that Congress has not specifically conferred" (Keynes and Miller 1989, 4). Under this theory, the courts are wholly at the mercy of Congress.

The plenary view may seem to grant Congress an immense advantage over the judiciary. "Congress could use its authority to emasculate the federal courts' power of judicial review. By eradicating federal jurisdiction over constitutional rights, Congress could upset the delicate balance of power between the legislative and judicial branches" (Keynes and Miller 1989, 7). While there is certainly a risk that Congress could simply choose to deprive the courts of all jurisdiction except that which is specifically provided in the Constitution, it seems quite unlikely. First, while Congress has historically proposed many bills to limit the courts' jurisdiction, the vast majority have never been enacted into law. Second, in order for such an extreme move to be politically palatable, the courts would have to become so unpopular that a sizable majority of the public would support eliminating wide swaths of the courts' jurisdiction. Given that a 57\% approval rating is considered unusually low for the Supreme Court, the courts would have to become incompetent or issue such unpopular decisions that most government agencies and citizens openly defy them to be seriously threatened by such sweeping proposals. Finally, "since the political branches realize that the use of federal courts is essential to administer federal law-for the purposes of both imposing government coercion and enforcing private remedies-Congress cannot, as a practical matter, withdraw all federal jurisdiction, even if it were authorized to do so 
constitutionally" (Choper 1980, 54). Government simply cannot function without the courts. It would be far more trouble for Congress to strip the courts of jurisdiction and erect new enforcement mechanisms for its laws than to reverse undesirable court decisions through statutory amendment and the influencing of judicial appointments.

Further undermining the plenary view is the understanding of judicial review articulated in the Federalist Papers. In Federalist No. 78, Alexander Hamilton argues that the judiciary must be able to invalidate laws that are inconsistent with the Constitution. "If it be said that the legislative body are themselves the constitutional judges of their own powers, and that the construction they put upon them is conclusive upon the other departments, it may be answered, that this cannot be the natural presumption, where it is not to be collected from any particular provisions in the Constitution" (Hamilton 1788). If Congress were able to prevent the courts from fulfilling this function by eliminating judicial review, it would be able to violate the Constitution without restraint.

While proponents of the plenary view emphasize the regulations and exceptions clause, supporters of the mandatory view focus on the vesting clause: "The judicial power of the United States, shall be vested in one Supreme Court, and in such inferior courts as the Congress may from time to time ordain and establish." Under this language, there must be a Supreme Court with the government's judicial power. "The only authority over the federal judiciary given to Congress in the original plan of article III was the discretion to establish and structure inferior courts, to distribute and allocate the jurisdiction of the federal courts among the Supreme Court and the inferior federal courts, and to make regulations of practice and procedure for these courts" (Clinton 1986, 1518). Proponents of this constitutional interpretation hold that the courts serve a fundamental place in the government; therefore, one branch cannot reduce another branch to insignificance. "Admittedly, the exceptions and regulations clause confers some power on Congress, but it does not permit the legislature to destroy the basic structure of government or vitiate the Framers' remedial purpose" (Keynes and Miller 1989, 8). On the other hand, without some check on the judiciary's power, there is the danger of what some scholars and commentators call the "imperial judiciary," a judiciary that supplants the legislative and executive functions of government and brazenly implements its own policy preferences. 
This risk, like the risks under the plenary view, is fairly low. First, courts are staffed by judges selected by the President and confirmed by the Senate. This must have a crucial influence on the jurisprudence of the courts. Peretti $(1999,130)$ notes that "most justices, most of the time, satisfy the ideological and policy expectations of their appointing presidents. This is to be expected given the great care with which most presidents evaluate the ideological credentials of their Supreme Court nominees." Courts can thus be checked by selecting jurists who will not regard their role as that of an official who is empowered to unilaterally change the law without reasonable legal grounds. Second, Congress can amend laws to nullify undesirable decisions. This was the option that lawmakers preferred when they were considering how to respond to the Court's national security decisions in the late 1950s. Undoubtedly Congress has the authority to amend statutes to help clarify their interpretation. This check is not as readily available in cases of constitutional interpretation due to the formidable majorities that must be assembled to ensure passage through Congress and ratification by the states of constitutional amendments. Whether by appointments or overruling interpretations, Congress has means at its disposal to check the judiciary without limiting its jurisdiction.

The middle ground between these two poles, generally speaking, is the view that Congress can restrict the courts' jurisdiction, but only with limits on that power. A number of limits have been proposed throughout the literature. One limitation proposed by scholars is that Congress cannot limit the jurisdiction of the courts such that the essential functions of the courts cannot be executed. "If the Court was intended the curb Congressional excesses in appropriately presented 'cases or controversies,' and if an attempt to exercise that power might in turn be blocked by Congress as a judicial 'excess,' then the Convention was aimlessly going in circles" (Berger 1969, 286). Congress cannot check the courts in such a way that the courts cannot check Congress.

Since the actual text of the Constitution does not mention any limits on Congress' power to alter the judiciary's jurisdiction, producing a list of the essential functions of the courts is an exercise in discerning what role the courts uniquely fill in government. Keynes and Miller $(1989,16)$ suggest that "[i]n a constitutional democracy, the courts must have judicial power to protect the rule of law, fundamental constitutional rights of individuals, and the rights of insular minorities." Courts are also supposed "to promote 
uniformity of decision, to assure national supremacy, to implement national law, to provide a neutral forum for out-of-state and foreign suitors, and to preserve the citizens' constitutional rights against popular oppression" (Keynes and Miller 1989, 17). Any congressional restrictions on the courts' jurisdiction that prevent them from fulfilling these essential functions are unconstitutional, according to this view.

The primary difficulty with this view is arguing that Congress' power to limit the courts' jurisdiction ends where the courts' essential functions begin is only another way of saying that Congress' powers end where the courts' powers begin. The branches of government disagree on which checks and balances apply to them and what powers are allocated to each of them. This is made clear by the argument of advocates for jurisdictional limitation that when the courts begin "legislating from the bench," they are usurping the essential functions of the legislative branch and Congress must check the courts to restore the proper balance of power.

In many cases, the Supreme Court and other federal judicial bodies not only have exceeded their constitutional limits, but have challenged the principle of federalism that should protect the balance of power between the national government and the governments of the states....America's Founding Fathers created a democratic republic in which elected representatives were to decide the important issues of the day. In their view, the role of the judiciary, although crucial, was to interpret and clarify the law-not to make law (Meese 1998, 782-83).

So if the three branches of government could simply agree upon their proper respective roles, they would not overstep their bounds and there would be no need for the branches to check each other, eliminating the need for congressional restrictions on the courts' jurisdiction. Since none of the branches can agree, they must check each other. However, since they do not agree on their proper powers or essential functions, one branch that is being limited by another claims that the limitation itself is improper and is upsetting the proper balance of power. The essential functions theory merely redefines the debate over the separation of powers that has existed since before the Constitution was ratified.

While this review of the debate over Congress' authority to limit 
the judiciary's jurisdiction is necessarily cursory, it provides a backdrop for examining what Congress has actually done to limit the courts' jurisdiction in recent years, a topic that has not been investigated extensively in the literature. I will now move from theoretical review to empirical observations on Congress' behavior toward the courts.

\section{The Empirical Study}

I studied the frequency and nature of congressional denials of jurisdiction from 1988 to 2004 to gain understanding of how the use of this authority affected the relationships between the three branches of the federal government. I conducted text searches on LexisNexis of public laws enacted between 1988 and 2004. This period was selected because it contained the earliest laws (the earliest is P.L. 100-243, enacted February 9, 1988) in LexisNexis at the time and went through the $108^{\text {th }}$ Congress.

I conducted two searches for each Congress. First, I searched for "judicial review." This is the most commonly used phrase to indicate review of laws and executive actions by the courts. I accessed each public law that appeared in the search results and then used the web browser's "Find in This Page" function to find "judicial review." An example of the phrase in statutory language might read: "There shall be no judicial review of any determination under this section by the Secretary." I read the text surrounding each occurrence of "judicial review" and determined whether the provision was an express denial of jurisdiction over a defined set of cases or a defined set of laws, rules, actions or decisions by any government agent. If I determined the provision was an express denial of jurisdiction, I recorded the public law number, Statutes At Large citation, the number of the section containing the provision, and the set of cases, rules or actions over which jurisdiction was denied in an appendix that is on file with the journal and author. ${ }^{1}$

Second, I conducted a broader search in case jurisdiction was denied but the language did not contain the phrase "judicial review." I searched for "court*." This search yielded any law that contained the word "court" and any letters thereafter (e.g., "courts," "courthouse," "courtroom"). I then searched within these results for

${ }^{1}$ If you have questions or would like to examine this appendix, please contact the author at benjamin.j.keele@gmail.com or the journal at psajournal@union.edu. 
the word "review." So, while the language "No court shall have jurisdiction to review any determination under this section by the Secretary," would not have been found in the first search, it would be found in the second search, thus providing a more complete count of provisions relating to judicial review. I repeated the "Find in This Page" procedure for any public laws I had not already searched.

For the purposes of this study, an express denial of jurisdiction is a provision of a public law that categorically and explicitly deprives the courts of jurisdiction to review or hear a defined class of cases, set of governmental actions, set of rules and regulations or set of statutory provisions, or that repeals a previously effective authorization of judicial review. It will be helpful to illustrate this definition with some examples that do not meet it.

Public Law 102-385, the Cable Television Consumer Protection and Competition Act of 1992, provides that any judicial review under the Act will be heard by a three-judge district court and any appeals from the district court shall go directly to the Supreme Court. This law, and many others like it, simply regulates the manner and forum in which judicial review may be had. Since jurisdiction is not completely denied but merely directed to specific places or in specific ways, such provisions are not congressional denials of jurisdiction for the purposes of this study. Also, many laws provide time limits for filing an action after which no court will have jurisdiction over the action. Again, these provisions are purely procedural in nature and are not the topic of this study.

Section 410 of Public Law 104-1, the Congressional Accountability Act of 1995, provides that "[e]xcept as expressly authorized by sections 407,408 , and 409 , the compliance or noncompliance with the provisions of this Act and any action taken pursuant to this Act shall not be subject to judicial review." Here judicial review is regulated and constrained to a set of specifically authorized circumstances and legal grounds. For instance, if an employee of Congress feels her statutory rights have been violated, she must first go through counseling and mediation. If she is still not satisfied, she may either file a complaint with a review board or file a civil action in a United States district court. If she goes to the review board and loses, she may only appeal to the United States Court of Appeals for the Federal Circuit. While judicial review is certainly being circumscribed, it is still available and thus laws that limit jurisdiction over an area of law but do not eliminate it are not counted in this study. 
The Illegal Immigration Reform and Immigrant Responsibility Act of 1996, Division C of Public Law 104-208, limits the remedies courts are able to utilize in immigration proceedings. For example, section 304 provides that "Any petition for review under section 242 of an order entered in absentia under this paragraph shall (except in cases described in section 242(b)(5)) be confined to (i) the validity of the notice provided to the alien, (ii) the reasons for the alien's not attending the proceeding, and (iii) whether or not the alien is removable." The legal grounds on which an alien can contest her deportation are limited by the law, but her ability to obtain judicial review is not utterly abolished.

The Anti-Terrorism and Effective Death Penalty Act of 1996 also limits remedies available in habeas corpus actions. According to the conference report for the Act, the law "sets a one year limitation on an application for a habeas writ and revises the procedures for consideration of a writ in federal court. It provides for the exhaustion of state remedies and requires deference to determinations of state courts" (U.S. House Committee of Conference 1996, 111). The Act also establishes other time limits within which the courts have jurisdiction over hearing appeals concerning new evidence. While prisoners have some access to the courts, this access is limited, although not eliminated, by the Act. Provisions that only limit but do not deny jurisdiction over a defined set of actions or rules are not counted in this study.

After collecting the data, I tabulated the number of provisions each Congress enacted that were express denials of jurisdiction. Because more than one denial of jurisdiction could be contained in one law, I also counted the number of laws within which these provisions were enacted. The table displaying these results is presented in the Findings.

This study focuses on cases in which Congress enacted laws that deprived the courts of jurisdiction over a defined set of actions, rules or cases between 1988 and 2004. Therefore, bills that were proposed but not enacted are not reflected in the findings. Laws that were enacted that regulate or partially limit the courts' jurisdiction have an important influence on the powers of the judiciary, but could not be counted under the definition of express denial of jurisdiction because including them would have required developing criteria for classifying the different degrees of restrictions on jurisdiction, a task too ambitious for a study of this scope. Finally, to have a complete picture of Congress's actions toward the judiciary's jurisdiction, 
cases in which Congress granted judicial review and expanded the courts' jurisdiction should be considered. Future studies should expand upon these findings by examining cases outside of this study's scope.

\section{Findings}

I found that between 1988 and 2004, Congress enacted 166 express denials of jurisdiction in 112 laws. The $104^{\text {th }}$ Congress (1995-1996) had the most denials at 27 , while the $103^{\text {rd }}$ Congress (1993-1994) had the fewest at seven. Since the second session of the $100^{\text {th }}$ Congress (1987-1988) alone had 19 denials, it is possible that the $100^{\text {th }}$ Congress may have actually passed the most. Table 1 presents the total number of denials enacted and the trends of denials over the studied period.

As the table shows, there is no recognizable trend in the number of denials enacted in each Congress. The $104^{\text {th }}$ Congress saw the enactment of the Prison Litigation Reform Act of 1995, the Illegal Immigration Reform and Immigrant Responsibility Act of 1996 and the Anti-Terrorism and Effective Death Penalty Act of 1996, all laws that significantly limited the jurisdiction of the courts. It is possible that the Republican Party, which had attained majority control of both houses of Congress in 1994, was finally implementing its preferences in these policy areas. The $107^{\text {th }}$ Congress was the Congress that dealt with the September 11, 2001 terrorist attacks. The $107^{\text {th }}$ Congress enacted the USA PATRIOT Act and other legislation that included denials of jurisdiction to increase government secrecy and empower the executive branch to deal with reforms necessary to bolster homeland security.

Other than the significant peaks in the $101^{\text {st }}, 104^{\text {th }}$ and $107^{\text {th }}$ Congresses, there is no pattern in the number of express denials of jurisdiction. It is worth noting, however, that Congress regularly enacts at least a half-dozen or more denials of jurisdiction in a twoyear period. While controversial and unpopular court decisions may spark a wave of jurisdiction-stripping proposals, a stream of jurisdictional denials constantly flows out of Congress without much publicity or prominent debate. 
Table 1: Enacted Denials by Congress, 1988-2004

\begin{tabular}{|c|c|c|c|c|}
\hline Congress & $\begin{array}{c}\text { Number } \\
\text { of } \\
\text { Express } \\
\text { Denials }\end{array}$ & $\begin{array}{c}\text { Number } \\
\text { of Public } \\
\text { Laws } \\
\text { with } \\
\text { Denials }\end{array}$ & $\begin{array}{c}\text { Total } \\
\text { Number } \\
\text { of Public } \\
\text { Laws } \\
\text { Enacted }\end{array}$ & $\begin{array}{c}\text { Percentage } \\
\text { of Public } \\
\text { Laws with } \\
\text { Denials }\end{array}$ \\
\hline $\begin{array}{l}100^{\text {th }} \\
\text { (1988 only) }\end{array}$ & 19 & 14 & 470 & $2.9 \%$ \\
\hline $\begin{array}{l}101^{\text {st }} \\
(1989-90)\end{array}$ & 26 & 18 & 650 & $2.7 \%$ \\
\hline $\begin{array}{l}102^{\text {nd }} \\
(1991-92)\end{array}$ & 13 & 10 & 590 & $1.6 \%$ \\
\hline $\begin{array}{l}103^{\text {rd }} \\
(1993-94)\end{array}$ & 7 & 6 & 465 & $1.2 \%$ \\
\hline $\begin{array}{l}104^{\text {th }} \\
(1995-96)\end{array}$ & 27 & 15 & 333 & $4.5 \%$ \\
\hline $\begin{array}{l}105^{\text {th }} \\
(1997-98)\end{array}$ & 19 & 10 & 394 & $2.5 \%$ \\
\hline $\begin{array}{l}106^{\text {th }} \\
(1999-00)\end{array}$ & 15 & 11 & 580 & $1.8 \%$ \\
\hline $\begin{array}{l}107^{\text {th }} \\
(2001-02)\end{array}$ & 26 & 16 & 377 & $4.2 \%$ \\
\hline $\begin{array}{l}108^{\text {th }} \\
(2003-04)\end{array}$ & 14 & 12 & 498 & $2.4 \%$ \\
\hline Total & 166 & 112 & 4357 & $2.5 \%$ \\
\hline
\end{tabular}

Most of the denials are narrow in scope. The majority of them relate to a specific decision or set of decisions by an executive branch official. Out of the 166 denials enacted in the studied period, 144 , or $86.7 \%$, shielded actions by executive branch officials. One example is P.L. 101-649. A provision in the law shields decisions by the Attorney General relating to granting or denying temporary protected status to aliens. Presumably Congress included the denial of judicial review because Congress did not want aliens whose requests for temporary protected status were denied to be able to delay their deportation by litigating the denial. Another example is P.L. 102-579. Several provisions in the law prevent judicial review of determinations regarding the safety of transporting and disposing of radioactive transuranic waste materials. Since the disposal of 
radioactive materials is controversial and opposed by environmental groups and the communities near the storage sites, Congress probably wished to prevent litigation from delaying the disposal of these dangerous materials.

Six denials, or $3.6 \%$ of the total number, bar judicial review of decisions made by administration officials in order to comply with international treaties. Certainly American foreign policy could be complicated by lawsuits challenging actions that are necessary for the United States to remain in compliance with its obligations to foreign nations. P.L. 100-330 blocks judicial review of orders to enforce a fisheries treaty between the United States and several Pacific Oceans islands. P.L. 100-418, the Omnibus Trade and Competitiveness Act of 1988 , contains provisions that deny the courts jurisdiction over actions by the government to enforce antidumping and countervailing duty laws. Traditionally the executive branch has been responsible for foreign relations and economic policy, so perhaps this was the rationale for keeping the judiciary from becoming involved in international trade disputes.

Twelve, or $7.2 \%$, of the denials place decisions over informant award programs outside of the judiciary's purview. The federal government has many award programs to provide incentives to informants and whistle-blowers. Awards are available for informing on insider trading (P.L. 100-704), defrauding the government (P.L. 101-123), falsifying drug statements (P.L. 102-282), making fraudulent telemarketing calls (P.L. 103-322), and conspiring to commit terrorist acts or traffic narcotics (P.L. 105-323). These jurisdictional exemptions seem to be justified on the basis of secrecy and efficiency. Gathering information from informants on any of a broad range of crimes requires secrecy to protect the integrity of the investigation and the security of the informants themselves. It would be difficult to protect informants and administer the awards program effectively if an informant could sue because she is displeased with the amount of her award.

Many actions relating to employees of the Central Intelligence Agency are immune to judicial review. Denials of jurisdiction over CIA personnel decisions were enacted three times in the studied period. P.L. 102-496 denied jurisdiction to review decisions relating to the CIA's retirement and disability system. P.L. 105-272 prevented courts from reviewing actions of the CIA Director and the CIA Inspector General relating to complaints from CIA employees. Finally, decisions relating to the compensation, insurance and taxes 
of undercover intelligence agents were shielded from judicial review by P.L. 108-487. Since it is difficult to maintain secrecy in civilian courts, it is likely that the CIA requested and Congress granted protection from judicial review over some of the ways the CIA deals with its agents and employees.

Five, or $3.0 \%$, of the denials of jurisdiction were used to settle disagreements over timber sale on federal land. Perhaps environmentalist advocacy groups were litigating or threatening to impede selling timber or building roads in national parks, so Congress made the decisions relating to selling timber or building roads in those parks unreviewable. For example, P.L. 100-446 finalized the Forest Service's plan to sell timber and build roads in the Silver Complex Fire Recovery Area of the Siskiyou National Forest and sell timber from the Mapleton Ranger District of the Siuslaw National Forest. Forest Service guidelines for selling timber in Washington and Oregon were at the center of a court dispute. In P.L. 101-121, Congress denied the courts jurisdiction to review any sales permitted by an agreement between the government and the plaintiffs.

Between 1988 and 2004, Congress enacted two denials covering federal laws and two denials related to administrative regulations. So the vast majority of denials of jurisdiction do not prevent review of legislation or regulations, the type of denial most frequently mentioned in the media. Rather, most of the denials are narrowly tailored to protect specific executive actions and decisions. Instead of passing the Marriage Protection Act to shield an entire section of the United States Code from review, Congress is enacting denials of jurisdiction like one contained in P.L. 108-7 that prevents courts from reviewing the distribution of payments to tobacco farmers.

\section{Discussion}

Because most unreviewable actions are undertaken in the executive branch, congressional denials of jurisdiction relate as much to the separation of powers between the judiciary and the executive as they relate to the separation between the judiciary and legislature. Determinations on the legality of many decisions are being made between members of Congress and administration officials, who then exclude the judiciary from participating. Since many of the decisions over which judicial review is prohibited are narrow in scope, related to national security (an area the judiciary tends to tread lightly in any 
case), or merely part of the implementation of a larger project that is judicially reviewable, the distortion this phenomenon has on the relationship between the three branches is probably slight.

It must be emphasized that if this study had undertaken the task of counting every grant of jurisdiction, the number of grants would far outweigh the number of denials. Denying jurisdiction, while more common than may be generally perceived, is still the exception to the rule of granting judicial review. However, the available data do not allow us to be certain that the practice has not become more common over time. While the number of jurisdictional denials over the last 16 years has been related to shifts of political power and catastrophic events, it is possible that the legislature and executive may be tending more often to exclude the judiciary from the decisionmaking process. If this practice becomes more prevalent, it will constitute a major shift of power from the judicial branch to the legislative and executive branches that draft and implement the laws.

Another aspect of the current practice of limiting the jurisdiction of the courts that may raise concern is the low level of public attention paid to it. While bills with sweeping and controversial denials of jurisdiction are heavily covered and debated in the news media, smaller denials of executive decisions are largely ignored. Ironically, the very characteristics of the proposals that are heavily discussed are also those that make it extremely unlikely that the bill will pass. The provisions that are likely to be enacted, however, are innocuously inserted into legislation and enacted without fanfare.

This lack of attention is due to several factors. First, the bills that contain these denials are not identified as bills to reduce the jurisdiction of the courts. Rather, they are presented as proposals to reform Medicare, to fund the Department of the Interior, or to implement an international treaty. The denial of jurisdiction is a minor detail, one sentence that surely is knowingly inserted but not carefully examined. Second, the areas over which jurisdiction is denied are generally narrow and obscure, hardly interesting material for a newspaper story or television broadcast. Third, since the set of people whose potential lawsuits are barred by the provision is relatively small (again because the scope of the denial is narrow), there are few people to complain when their ability to be heard in court is threatened.

The lack of publicity over this aspect of the relationship between the branches of government also carries the risk that American citizens, happily presuming that their interests, if necessary, can be 
vindicated in court, are actually having their right to be heard in court quietly taken away from them. Provisions of the AntiTerrorism and Effective Death Penalty Act of 1996 and USA PATRIOT Act restrict judicial review over important individual rights (habeas corpus review and national security letters, respectively) but do not entirely eliminate it and thus were not counted in this study. Nonetheless, if the practice of denying the courts jurisdiction outright becomes more commonplace, important rights over which judicial review is currently circumscribed may be barred from the courthouse.

Certainly the executive and legislative branches are politically accountable, but the voters cannot vote for or against a candidate on the basis of information they do not possess. To mention a parallel case, no legislator need fear severe electoral repercussions for his vote on the intelligence budget, because the budget is classified. Likewise, provisions that are unclassified but so obscure as to be virtually unknown to the electorate do not have consequences at the ballot box. Many of the jurisdictional denials are buried in large and complex pieces of legislation. This makes it difficult for citizens, the press, or even most legislators to notice the denials and voice any concerns.

If this is the case, which branch is most likely to make wise policy decisions and protect individual rights? It is difficult to say. On the one hand, Congress and the administration possess information and experience that is unavailable to the courts. On the other hand, the executive's and legislature's enmeshment in the political process and the influences of interest groups that affect it may mean that some groups are unjustly harmed by decisions that are also rendered immune to judicial review. As one scholar wrote about the Founders' view of the courts, "the supporters of the Constitution believed that the most dangerous branch, the one with the greatest capacity to annoy or injure rights, would be the legislature, because, through it, a majority actuated by a sense of injustice could effect its designs" (Kozlowski 2003, 85-86, emphasis in original). The courts are supposed to protect rights and invalidate actions that violate legal rights. It may be true that the decisions Congress has protected from judicial review would have passed muster and the denial of jurisdiction merely made the administration of public policy more efficient. However, there is no way of knowing this because any level of judicial review has been foreclosed by the jurisdictional denial. Congressional denial of the courts' 
jurisdiction and the public's low level of awareness of the practice raise issues relating to the transparency of executive decision-making and individual rights.

\section{Conclusion}

This study has revealed what is a largely unexamined practice in congressional and executive policy-making: shielding executive determinations from judicial review. Regardless of whether Congress is appropriately exercising its constitutional authority, history demonstrates that Congress has proposed and passed legislation denying jurisdiction over certain cases and decisions. Again, it must be acknowledged that Congress grants judicial review far more often than it denies it. But it must also be recognized that the practice in which Congress and the executive branch are engaged raises concerns for the future of the constitutional separation of powers, open governance and protection of individual rights.

Further studies should be conducted to determine more accurately the nature of the denials of jurisdiction, the public perception (or lack thereof) of this governmental behavior, how the judiciary has responded to these denials, and the historical trends prior to 1988. This information will help us better assess the wisdom and propriety of Congress' use of its power to make exceptions to and regulations of the judiciary's jurisdiction.

\section{References}

Bazon, Elizabeth B., Johnny Killian and Kenneth R. Thomas. 2005. Congressional Authority Over the Federal Courts. Congressional Research Service. Report RL32926.

Berger, Raoul. 1969. Congress v. the Supreme Court. Cambridge: Harvard University Press.

Biskupic, Joan and Elder Witt. 1997. The Supreme Court and the Powers of American Government. Washington: Congressional Quarterly.

Choper, Jesse H. 1980. Judicial Review and the National Political Process: A Functional Reconsideration of the Role of the Supreme Court. Chicago: University of Chicago Press.

Clinton, Robert N. 1986 "A Mandatory View of Federal Court Jurisdiction: Early Implementation of and Departures from the Constitutional Plan." Columbia Law Review 86:1515-1621. 
Gunther, Gerald. 1984. "Congressional Power to Curtail Federal Court Jurisdiction: An Opinionated Guide to the Ongoing Debate." Stanford Law Review 36:895-922.

Hamilton, Alexander. 1788. "Federalist No. 78." http://thomas. loc.gov/home/histdox/ fed_78.html (Dec. 27, 2007).

Keynes, Edward and Randall K. Miller. 1989. The Court vs. Congress: Prayer, Busing, and Abortion. Durham, NC: Duke University Press.

Kozlowski, Mark. 2003. The Myth of the Imperial Judiciary: Why the Right Is Wrong about the Courts. New York: New York University Press.

Meese III, Edwin. 1998. "Judicial Review and Judicial Independence: Putting the Federal Judiciary Back on the Constitutional Track." Georgia State University Law Review 14: 781-794.

Pew Research Center for the People and the Press. 2005. "Supreme Court's Image Declines as Nomination Battles Loom: Court Critics Now on Both Left and Right," June 15. http://peoplepress.org/reports/pdf/247.pdf (Nov. 1, 2005).

Peretti, Terri Jennings. 1999. In Defense of a Political Court. Princeton: Princeton University Press.

Pritchett, C. Herman. 1961. Congress Versus the Supreme Court 1957-1960. Minneapolis: University of Minnesota Press.

Tushnet, Mark and Jennifer Jaff. 1984. "Why the Debate Over Congress' Power to Restrict the Jurisdiction of the Federal Courts is Unending." Georgetown Law Journal 72:1311-1332.

U.S. Congress. House. Committee of Conference. 1996. Terrorism Prevention Act. $104^{\text {th }}$ Cong., $2^{\text {nd }}$ sess. H. Rept. 104-518.

U.S. Congress. House. Committee on the Judiciary. 2004. Marriage Protection Act of 2004. $108^{\text {th }}$ Cong., $2^{\text {nd }}$ sess. H. Rept. 108-614. 
Appendix to Benjamin Keele, “Ganging Up Against the Courts: Congressional Curtailment of Judicial Review, 1988-2004

Express Congressional Denials of Judicial Review Between the $100^{\text {th }}$ and $108^{\text {th }}$ Congress

Statutory Provision

P.L. 100-274, 102 Stat. $48, \S 3$

P.L. 100-330, 102 Stat. 591, §11

P.L. 100-418, 102 Stat. $1107, \S 1316$

Ibid, $§ 1320$

Ibid, $\$ 1321$
Law or Action not Reviewable

Determination by Secretary to acquire materials and services for the production of coinage from foreign sources.

Orders by the Secretary enforcing the Treaty on Fisheries Between the Governments of Certain Pacific Island States and the Government of the United States of America Determinations by the administering authority that a country does not operate under a market economy

Determinations by the administering authority relating to monitoring in trade a downstream product

Decisions by the administering authority relating to categorizing merchandise proposed for inclusion in antidumping and countervailing duties orders 
Ibid, $§ 5021$

P.L. 100-427, 102 Stat. 1603, §25

P.L. $100-435,102$ Stat. $1645, \S 603$

P.L. 100-446, 102 Stat. 1774, $§ 320$

Ibid, $\$ 321$

P.L. 100-449, 102 Stat. 1851, $\$ 401$
Provisions of 50 USCS Appx $§ 2170(d)$, which

prescribe the determinations the President must

make before suspending or prohibiting an

acquisition, merger or takeover of a person

engaged in interstate commerce that threaten

national security

Decisions by the Secretary not to

permit tribal governments' use of Bureau of

Indian Affairs facilities

Determinations by the Secretary concerning whether a State agency had good cause for its

failure to meet error tolerance levels

Final Environmental Impact Statement, Record

of Decision, and Forest Service decisions relating

to timber sales and road construction in the Silver

Complex Fire Recovery Area of the Siskiyou

National Forest.

Decisions by Secretary to sell timber from the Mapleton Ranger District of the Siuslaw National Forest.

Decisions by administering authority or United

States Customs Service to suspend liquidation of entries of merchandise. 
Ibid, $\$ 403$

P.L. 100-499, 102 Stat. 2491, §6

P.L. 100-532, 102 Stat. 2654, §102

P.L. 100-547, 102 Stat. 2736, $§ 202$

P.L. $100-653,102$ Stat. $3825, \S 703$

P.L. 100-678, 102 Stat. $4049, \S 6$

P.L. $100-690,102$ Stat. $4181, \S 7522$

P.L. 100-704, 102 Stat. 4677, §3

P.L. 101-73, 103 Stat. 183, §212
Decisions regarding the disclosure or nondisclosure of material under protective order. The RARE II Final Environmental Statement of January 1979 with respect to the National Forest System in Oklahoma.

Content of list of registered pesticides and guidelines for formatting studies and identifying information that may not meet regulatory requirements.

The RARE II Final Environmental

Statement of January 1979 with respect to the

National Forest System in Alabama.

Valuations of in-kind contributions and personal property from California to pay for cost of study of fishery resources in the Russian River basin.

Determinations that noncompliance with building codes or zoning laws is necessary for national security.

Decisions to retain or transfer to other agencies materials that are subject to civil forfeiture. Determinations to award bounties to informants. Determinations to deny claims or portions of claims; claims for payment from any institution 
over which the Corporation is receiver or for actions or omissions of the Corporation as receiver.

Ibid, $§ 301$

Determinations not to disclose information in reports of savings associations.

Ibid, $\$ 1118$

Decisions of Appraisal Subcommittee on recognizing state appraiser certifying and licensing agencies.

Ibid, $§ 1217$

Decisions by the liquidating agent to disallow claims; claims for payment from any institution over which the liquidating agent is receiver or for actions or omissions of the liquidating agent as receiver.

P.L. 101-121, 103 Stat. 701, §318 Forest Service Guidelines concerning timber sales in Washington and Oregon; timber sales permitted by agreement between the Forest Service and plaintiffs.

P.L. 101-123, 103 Stat. 759, §2 Failure of the Attorney General to make payments to whistleblowers.

P.L. 101-189, 103 Stat. 1352, $\$ 1301$ Denials of review by Court of Military Appeals not subject to certiorari review by Supreme Court. 
P.L. 101-195, 103 Stat. 1784, §5

P.L. 101-222, 103 Stat. 1892, $\$ 6$

P.L. 101-239, 103 Stat. 2106, $§ 6003$

Ibid, $§ 6102$

P.L. 101-401, 104, Stat. 863, §5

P.L. 101-452, 104, Stat. 1054, §5

P.L. 101-508, 104 Stat. 1388, $§ 10301$
The RARE II Final Environmental

Statement of January 1979 with respect to the

National Forest System in Nevada.

Designations of items as defense articles or

defense services.

Decisions of the Secretary on changing the

geographic classification of hospitals.

Determinations of historical payment bases,

relative values and relative value units,

conversion factors; establishment of geographic

adjustment factors and a system for the coding of physicians' services.

The RARE II Final Environmental

Statement of January 1979 with respect to the

National Forest System in Maine.

Valuations of in-kind contributions and personal

property from Washington to pay for cost of

study of fishery resources in the Chehalis River

Basin.

Estimates of number of expected aliens and amount of the United States Travel and Tourism

Facilitation Fee for a given calendar year. 
P.L. 101-549, 104 Stat. 2399, $\$ 228$

Ibid, $§ 301$

Ibid, $\$ 401$

Ibid, $\$ 701$

P.L. 101-552, 104 Stat. 2736, \$4

P.L. 101-592, 104 Stat. 2943, $\$ 9$

P.L. 101-601, 104 Stat. 3048, §9

P.L. 101-625, 104 Stat. 4079, §108
Determinations to assess a civil penalty exceeding $\$ 200,000$.

Determinations of priorities for the promulgation of emission standards; reports of the Chemical Safety and Hazard Investigation Board.

Corrections or failures to correct data affecting

Phase II units' baselines and actual 1985

emissions rates.

Determinations to assess civil penalties greater than $\$ 200,000$ or assessing civil penalties on violations that occurred more than 12 months ago.

Agency decisions to use or not use arbitration procedures; decisions to terminate arbitration proceedings or vacate an arbitral award.

Final civil penalties not subject to review in recovery actions.

Final civil penalties not subject to review in recovery actions.

Explanations in jurisdictions' reports regarding the effect of public policies on affordable housing. 
P.L. 101-647, 104, Stat. 4789, §2587

P.L. 101-648, 104. Stat. 4969, §3

P.L. 101-649, 104. Stat. 4978, $§ 302$

P.L. 102-29 105 Stat. $169, \S 3$

P.L. 102-240, 105 Stat. 1914, §2502

P.L. 102-282, 106 Stat. 149, §3

P.L. 102-306, 106 Stat. $260, \S 4$

P.L. 102-325, 106 Stat. $448, \S 1317$

P.L. 102-344, 106 Stat. 921, §2
Decisions by the Attorney General to award or not award payments to informants of financial institution offenses.

Agency actions establishing, assisting or terminating negotiated rulemaking committees.

Determinations of Attorney General relating to temporary protected status of aliens.

Determinations and reports by Special Board mediating railroad labor disputes.

Notice of delayed action extension of comment period or completion period on proposed rulemaking regarding motor vehicle safety.

Final civil penalties not subject to review in recovery actions; informant awards.

Decisions of arbiter in mediating railroad labor disputes.

Regulations relating to higher education tribal grants.

Determinations by the Director of the Census triggering a bilingual voting materials requirement. 
P.L. 102-496, 106 Stat. $3180, \S 802$

P.L. 102-567, 106 Stat. $4270, \S 811$

P.L. 102-579, 106 Stat. $4777, \S 6$

Ibid, $\S 7$

Ibid, §8

Ibid, §16

P.L. 102-587, 106 Stat. 5039, $§ 8011$

P.L. 103-66, 107 Stat. $312, \$ 6003$

P.L. 103-322, 108 Stat. $1796, \S 60009$
Determinations by the Director of Central

Intelligence relating to the Central Intelligence Agency Retirement and Disability System.

Final civil penalties not subject to review in recovery actions.

Determinations and certifications by various officials preceding the commencement of test phase for disposing of transuranic waste.

Survey required before commencement of disposal of transuranic waste.

Determinations by Administrators regarding facility's compliance with final disposal regulations.

Determinations by Nuclear Regulatory Commission that packages for transporting transuranic waste meets quality assurance requirements.

Final civil penalties not subject to review in recovery actions.

Changes in Federal Communications Commission regulatory fees.

Determinations by Attorney General that foreign murder of a United States national took place in 
country in which the person is no longer present and the country lacks the ability to lawfully secure the person's return.

Ibid, $\$ 250004$

Decisions of Attorney General relating to awards to informants.

P.L. 103-354, 108 Stat. $3178, \S 304$

§304, which establishes the Office of Risk

Assessment and Cost-Benefit Analysis in the U.S.

Department of Agriculture.

P.L. 103-407, 108 Stat. $4210, \S 8$

Final civil penalties not subject to review in recovery actions.

P.L. 103-438, 108 Stat. 4597, $\$ 9$

Determinations regarding foreign cooperation in antitrust investigations.

P.L. 103-465, 108 Stat. $4809, \S 801$

Award by the Federal Communications

Commission of preferences and awards released

February 3, 1994.

P.L. 104-13, 109 Stat. $163, \S 2$

Determinations by Director to approve or not act upon a collection of information contained in an agency rule.

P.L. 104-99, 110 Stat. $26, \S 407$

Actions by Secretary relating to foreclosure avoidance.

P.L. 104-121, 110 Stat. 847, $\$ 212$

Small entity compliance guides.

Ibid, $\$ 251$

Congressional review and disapproval of administrative rules. 
P.L. 104-130, 110 Stat. $1200, \S 2$

P.L. 104-132, 110 Stat. $1214, \S 401$

Ibid, $\$ 440$

Ibid, $\$ 815$

P.L. 104-134, 110 Stat. 1321, Title II

P.L. 104-164, 110 Stat. 1421, $\$ 157$

P.L. 104-170, 110 Stat. $1489, \$ 210$

Ibid, $\$ 405$

P.L. 104-182, 110 Stat. 1613, $§ 102$

P.L. 104-201, 110 Stat. 2422, $§ 657$

P.L. 104-204, 110 Stat. 2874, $\$ 427$
Congressional identification of limited tax benefits.

Continued detention of aliens except when constitutional claims invoked.

Deportation orders of aliens who have committed certain offenses.

Decisions of Attorney General relating to awards to informants.

Determination by Forest Service to permit sale of timber from Alaska.

Presidential determinations to impose sanctions on those contributing to nuclear proliferation. Failure of the Administrator to complete reviews of pesticides for minor uses within 12 months.

List of priorities for the review of tolerations and exemptions for chemical pesticide residues.

Decisions to include unregulated drinking water contaminants on a list of contaminants that may require regulation.

Determinations relating to payments made to certain prisoners of war in the Vietnam War.

Decisions to cancel delegations of authority to insure certain mortgages. 
P.L. 104-208, 110 Stat. 3009, Div. A, $\$ 110$ Decision by Attorney General to terminate the Department of Justice Telecommunications Carrier Compliance Fund.

Ibid, Div. A, $§ 664$

The Electronic Benefit Transfer Pilot project.

Ibid, Div. A, $§ 2504$

40 CFR 300.1105 as issued April 29, 1992.

Ibid, Div. A, $§ 5203$

Decision by Authority to issue orders, rules or regulations.

Ibid, Div. C, $§ 303$

Decisions of the Attorney General regarding the detention and release of illegal aliens.

Ibid, Div. C, $\S^{304}$

Decisions to deny orders of voluntary departure.

Ibid, Div. C, $§ 306$

Various matters and forms of review relating to removal of illegal aliens.

Ibid, Div. C, §343

Determinations relating to the admission of foreign health-care workers.

Ibid, Div. C, §604

Determinations relating to an alien's eligibility to apply for asylum.

P.L. 104-227, 110 Stat. 3034, §104

Determinations and actions relating to environmental impact assessment of Antarctic joint activities.

P.L. 104-237, 110 Stat. 3099, $\$ 401$ Extension of application of law to sale to certain pseudoephedrine or phenylpropanolamine drug products for six months.

P.L. 104-333, 110 Stat. 4093, $§ 304$ Exchange of land in Utah. 
P.L. 105-33, 111 Stat. 251, \$4421

Ibid, $\$ 4454$

Ibid, $\$ 4523$

Ibid, $\$ 4531$

Ibid, $§ 4603$

P.L. 105-65, 111 Stat. 1344, $§ 516$

P.L. 105-100, 111 Stat. 2160, $\$ 202$

Ibid, $\S 203$

P.L. 105-185, 112 Stat. 523, $§ 502$
Classifications and payment rates for inpatient rehabilitation services.

Estimates of expenditures and reductions of expenditures for coverage of religious nonmedical health care institutional services.

Classifications and payment rates for a prospective payment system for hospital outpatient department services.

Fee schedule for ambulance services.

Payments and adjustments for a prospective payment system for home health services.

Determinations not to not consider restructure mortgages or renew contracts.

P.L. 105-85, 111 Stat. 1629, Div. A, §603 Determinations relating to housing allowances for uniformed members of the military.

Decisions to adjust the status of certain aliens from Nicaragua or Cuba.

Determinations that aliens meet criteria needed to waive certain provisions of immigration laws.

Determinations of amounts of funds attributable to benefiting programs and decisions by administrative law judges and departmental appeals board. 
P.L. 105-272, 112 Stat. 2396, $§ 702$

Ibid, Div. C, $\$ 413$

Ibid, Div. G, §2202

Ibid, Div. I, $\$ 303$

P.L. 105-292, 112 Stat. $2787, \$ 410$

P.L. 105-315, 112 Stat. 2993, $§ 9$

P.L. 105-323, 112 Stat. $3029, \S 101$

Ibid, $§ 102$

P.L. 106-107, 113 Stat. 1486, $\$ 9$

P.L. 106-113, 113 Stat. 1501, §1000,
Actions of Director and Inspector General relating to complaints of urgent concern from CIA employees.

P.L. 105-277, 112 Stat. 2681, Div. A, $\$ 101$ Decisions to adjust the status of certain aliens from Haiti.

Determinations of Secretary not to comply with notice requirements because to do so would interfere with efforts to secure employers' compliance.

Determinations by the Secretary of State to reward informants.

Objections by the President to individuals' serving as inspectors of United States plants and facilities.

Any presidential determinations, agency actions or amendments under the Act.

Arbitration awards.

Determinations by the Secretary of State to reward informants.

Determinations by the Secretary of State to reward informants.

Agency compliance with the Act. 
H.R. 3426, §201

P.L. 106-120, 113 Stat. 1606, §805

P.L. 106-185, 114 Stat. 202, §15

P.L. 106-224, 114 Stat. 358, $\$ 415$

P.L. 106-265, 114 Stat. $762, \S 2208$

P.L. 106-393, 114 Stat. 1607, $\$ 204$

P.L. 106-396, 114 Stat. 1637, $\$ 203$

P.L. 106-553, 114 Stat. 2762, §1,

H.R. 5548, §1004

P.L. 106-554, 114 Stat. 2763, H.R. 5661, \$412

Ibid, H.R. 5661, §521

Ibid, H.R. $5662, \S 308$
Adjustments to various payment rates for medical services.

Designation of foreign narcotics traffickers and blocking of assets.

Decisions to certify foreign requests for enforcement of forfeiture judgments.

Amount of compensation paid to people for economic losses due to measures taken to quarantine or destroy dangerous plants. Corrections to federal retirement coverage. Rejection of projects proposed by resource advisory committees.

Denial of a visa on the grounds of inadmissibility. Decisions of Board relating to loan guarantees.

Various decisions relating to physician group practice demonstration projects. Regulation that determines a method for determining the amount of payment under Medicare part B that was initially issued before January $1,1981$.

Adjustments made to the Consumer Price Index. 
P.L. 106-569, 114 Stat. 2944, $\$ 708$

P.L. 107-11, 115 Stat. 19, §3

P.L. 107-42, 115 Stat. $230, \$ 405$

P.L. 107-56, 115 Stat. 272, §501

P.L. 107-71, 115 Stat. 704, $\$ 118$

Ibid, $\$ 119$

P.L. 107-76, 115 Stat. 704, $\$ 759$

Ibid, $\$ 772$

P.L. 107-118, 115 Stat. 2356, §102

P.L. 107-123, 115 Stat. 2390, §3

Ibid, §4
Final civil penalties not subject to review in recovery actions.

Planning and design of the World War II memorial.

Determinations by the Special Master relating to compensation to victims of the September 11 terrorist attacks.

Determinations by the Attorney General to reward informants.

Estimates of costs of civil aviation personnel, limitations on security service fees.

Determinations on the Administrator relating to aviation fees.

Determination that a majority of producers of each kind of tobacco vote in referenda in favor of mandatory grading.

Distribution of payments to tobacco farmers.

Determinations by the President to not allow de micromis exemption from liability for disposing of hazardous materials or to allow expedited settlements.

Adjustments of securities transaction fees. Adjustments of registration fees. 
Ibid, §5

Ibid, $§ 6$

P.L. 107-171, 116 Stat. 134, $\$ 1613$

Ibid, $\$ 4118$

Ibid, $\$ 4120$

Ibid, $\$ 10407$

P.L. 107-188, 116 Stat. 594, $\$ 102$

P.L. 107-206, 116 Stat. $820, \$ 706$

P.L. 107-273, 116 Stat. 1588, §201

Ibid, §11042
Adjustments to stock repurchase statement fees. Adjustments to fees for proxy solicitations and statements in corporate control transactions. Decisions to grant equitable relief from ineligibility for payments or other benefits. National performance measures relating to the food stamp program; decisions relating to States' payment and investment of liabilities.

Decisions to award bonus payments to States that demonstrate improved performance.

Determinations of compensation to be paid to owners of animals or products quarantined or destroyed.

Determinations of military necessity when activating National Disaster Medical System. Action to reduce fire and beetle risks in national forests.

P.L. 107-210, 116 Stat. 933, Div. E, §5101 Adjustment of annual payments to wool manufacturers. Determinations by the Attorney General to reward informants. Orders relating to discipline of judges. 
P.L. 107-228, 116 Stat. 1350, Div. B, \$1404 Final civil penalties not subject to review in recovery actions.

P.L. 107-296, 116 Stat. 2135, $\$ 425$

Denials of requests relating to explosive detection systems.

P.L. 107-297, 116 Stat. 2322, $\$ 102$

Certification of an act as an act of terrorism.

Ibid, $\$ 103$

Determinations relating to insured shared loss compensation.

P.L. 107-314, 116 Stat. 2458, §1065

Determinations by the Secretary of Defense to reward informants.

P.L. 108-7, 117 Stat. 11, Div. F, $§ 335$

Record of Decision for the 2003 Supplemental

Environmental Impact Statement for the 1997

Tongrass Land Management Plan.

Ibid, Div. N, $\$ 205$

Distribution of payments to tobacco farmers.

P.L. 108-20, 117 Stat. $638, \S 2$

Determines relating to compensation for injuries related to smallpox vaccination.

P.L. 108-89, 117 Stat. 1131, $\$ 401$

Delaying implementation of provisions equalizing urban and rural standardized Medicare inpatient hospital payments.

P.L. 108-173, 117 Stat. 2066, §105 Determinations not to endorse or contract with a prescription drug card sponsor.

Ibid, $§ 211$ Revision of MA capitation rates and application of payment rates. 
P.L. 108-276, 118 Stat. $835, \S 3$

P.L. 108-282, 118 Stat. $891, \S 102$

P.L. 108-334, 118 Stat. 1298, Title II

P.L. 108-375, 118 Stat. 1811, Div. A, $§ 326$

P.L. $108-458,118$ Stat. $3638, \S 5304$

P.L. 108-487, 118 Stat. $3939, \S 402$
P.L. 108-405, 118 Stat. $2260, \S 102$

Provisions in contracts for biomedical

countermeasures requiring specific quantities and

decisions to extend deadlines for proposals for

biomedical countermeasures.

Decisions to extend the conditional approval

period during review of a new minor animal drug.

Decisions to set the air carrier fee.

federal employees involved in public-private

competition.

Complaints relating to the denial of crime victims'

rights.

P.L. 108-447, 118 Stat. 2809 , Div. J, $\$ 424$ Determinations of Secretary not to comply with notice requirements because to do so would interfere with efforts to secure employers'

compliance.

Revocation of visas and other travel

documentation.

Determinations relating to the compensation, insurance, and taxes of nonofficial cover intelligence officers. 